\title{
DOES EFFICIENCY PROMOTE COMPETITIVENESS OF THE INSURANCE INDUSTRY?
}

\author{
Hui Shan $\mathrm{LEE}^{1,2^{*}}$, Fan Fah $\mathrm{CHENG}^{2}$, Annuar Md NASSIR ${ }^{2}$, \\ Nazrul Hisyam Ab RAZAK ${ }^{2}$ \\ ${ }^{1}$ Faculty of Accountancy and Management, Universiti Tunku Abdul Rahman, \\ Selangor, Malaysia \\ ${ }^{2}$ Faculty of Economics and Management, Universiti Putra Malaysia, \\ Selangor, Malaysia
}

Received 14 October 2017; accepted 17 May 2018

\begin{abstract}
This paper contributes to the existing literature by examining the efficiency and competitiveness of the Takaful insurance. We employ the Data Envelopment Analysis (DEA) to compute the efficiency of Takaful operators, while Panzar-Rosse (P-R) H-statistic method is used to evaluate the degree of competition. The findings indicate that the inefficiency in Takaful's operations is affected by the scale of operations but not by inefficiency in managerial practice. Actuaries need to pay attention to estimating provisions for outstanding claims, as this factor is negatively influencing the efficiency of Takaful insurance. Additionally, the managers are cautioned not to overspend on commissions paid to the agents because this will reduce the profit of the Takaful operators. The findings to a very large extent indicate that improvement in efficiency will increase the entry of a more viable competitor to participate in the Takaful industry. The regulators need to implement prudent monitoring of the operations of Takaful insurers because improvements in efficiency will make Takaful operators more competitive. The implications further shed light on the motivation for insurance firms to improve efficiency that enable them to charge lower price to enhance competition which may benefit both the firms and customers.
\end{abstract}

Keywords: data envelopment analysis, efficiency, Takaful insurance, Panzar-Rosse, competition, risk based capital framework.

JEL Classification: G22, C61, C67, L1.

${ }^{\star}$ Corresponding author. E-mail: hslee@utar.edu.my 


\section{Introduction}

The insurance industry, inclusive of Islamic insurance (Takaful ${ }^{1}$ ), is a financial institution that provides risk management services, smoothes consumption, produces liquidity, diversifies financial losses and facilitates investment in an economy, as recorded by Fah and Sin (2014)provider of financial services and risk transferor. These important roles have created strong demand for insurance products. Strong financial fundamentals combined with industry strength are vital for insurance-based companies to continuously do well in their business. This paper analyses the Earnings Response Coefficients (ERCs, Biener, Eling and Wirfs (2016) and Lee, Low, Chong and Sia (2018), in addition to its importance in reducing potential credit crises that slow potential bank run disasters. Takaful emphasises the need for transactions to be supported by genuine (Halal) trade or business-related activities and to be governed by Islamic finance law to set a higher standard for investments and promote greater accountability and risk mitigation. Recently, the global spread of Islamic finance has integrated the financial systems of Muslim countries that serve to strengthen the global financial markets. The recent financial world emphasises the importance of Takaful as a significant component of global Islamic finance that requires more attention and research so that it can address key issues and accomplish long-term growth. This study examine the efficiency and competitiveness of family Takaful and general Takaful industries in Malaysia because the Malaysian Takaful industry postulates the highest Takaful premium, penetration and density among the Islamic countries and records continuous positive growth momentum that leads the global Takaful markets (Goud, 2016) like all insurers in emerging market economies dependent on commodity prices, face a challenging year ahead. They also face additional challenges from inadequate regulation (and inadequate enforcement of regulation. Lee et al. (2018) indicated that emerging markets offer plenty growth prospect for insurance companies and Sufian (2011) believed that the Asian financial reform after the Asian financial crisis in 1997 will enable financial institutions in Asian countries to take advantage of economies of scale. Thus, Malaysia as a less developed economy in Asia would be an ideal testing ground for various hypotheses.

Several specific issues motivate the development of this paper. The ultimate choice of Takaful operator is driven by many factors, for example, operational efficiency, structure of the business (such as general or family Takaful) and profitability goals. Goud (2016) like all insurers in emerging market economies dependent on commodity prices, face a challenging year ahead. They also face additional challenges from inadequate regulation (and inadequate enforcement of regulation suggest that if the complicated Takaful model is not fully developed and tested, Takaful operation systems would behave poorly. This might result in dissatisfaction among the customers and inefficiency of Takaful business and lead to instability in Islamic finance. Thus, this paper raises the question "what are the factors that impact the

\footnotetext{
1 See Kader et al. (2010) and Coolen-Maturi (2013). Takaful is the Shariah-compliant alternative to conventional insurance that avoids prohibited. concepts to conform to Islamic jurisprudence, such as uncertainty (Gharar), gambling (Maysir) and interest (Riba). In the event of loss or damage, the Takaful operator will disburse the funds accordingly to its participants. Any surplus is paid out only after the obligation of assisting the participants has been fulfilled. Through this principle, Takaful operates as a protection and profit-sharing venture between the Takaful operator and the participants.
} 
efficiency of Takaful insurance"? Next, the structure of the Takaful sector (family vs. general Takaful) differs fundamentally: general Takaful is dominant in the majority of Islamic countries, such as Iran and Saudi Arabia, but family Takaful is dominant in Malaysia (Asia Insurance Review, 2016). According to the Malaysian Takaful Association Annual Report (2015), the gross contribution of family Takaful is RM3.4 billion, compared to a gross contribution of general Takaful of RM2.3 billion; thus, nearly two-thirds of the contributions are from family Takaful due to an increasing awareness among Malaysians of the importance of life protection and increasing acceptance of family Takaful products. Hence, it is interesting to compare the efficiency of family Takaful and general Takaful in Malaysia considering that general Takaful is dominant worldwide but family Takaful is dominant in Malaysia. On the other hand, the generation of healthy competition in Takaful insurance will benefit consumers (The Financial Stability and Payment Systems Report, 2015), but competitive pressure in Takaful insurance driven by too many small Takaful operators will lead to a threat that decreases the chances for the long-term success of Takaful operators (Goud, 2016) like all insurers in emerging market economies dependent on commodity prices, face a challenging year ahead. They also face additional challenges from inadequate regulation (and inadequate enforcement of regulation. The insurance industry shall be moving from monopoly to monopolistic competition to ensure the public welfare, but not under conditions of perfect market competition involving price wars that could place the insurers in an inferior position (Jeng, 2015). Therefore, it is also important to investigate the market structure of Takaful insurance in Malaysia to ensure the healthy growth of Takaful business. Lastly, merely assessing the competitiveness of insurance will only yield minimal implications; it is advisable to examine the relationship between efficiency and competitiveness, because intense competition will shorten the long-term relationships between insurers and policyholders and result in increased inefficiency of insurers (Alhassan \& Biekpe, 2016; Cummins, Rubio-Misas, \& Vencappa, 2017). In this vein, this paper attempts to investigate the effects of efficiency on the competitiveness of Takaful insurance in Malaysia and to examine whether the efficiency of Takaful insurance operators in Malaysia could be enhanced in such a way as to improve competition within the Takaful industry but still make it possible to keep the system from evolving into a perfectly competitive Takaful industry, thereby securing the financial stability of Islamic finance.

The objectives of this paper are fivefold. First, it will examine the factors that influence the efficiency of Takaful insurance in Malaysia. This will allow the managers of the Takaful operators to identify the factors that significantly influence the efficiency of Takaful operators and guide them in the decision making to improve the efficiency of the firms. Particularly, the factor of provision for outstanding claims is to be examined as insufficient provision could result in default of Takaful operators. Second, the comparison between the efficiency of family Takaful and general Takaful is to be investigated to shed some light on the dominant strategy of Malaysian Takaful on family Takaful whereas most countries are focusing on general Takaful. Third, this study will identify the Takaful market structure in Malaysia by employing the Panzar-Rosse (P-R) method. It will also examine the factors that influence the evolution of Takaful competition. This analysis is important to the regulators in identifying which Takaful firm-specific factors require more attention with respect to improving 
Takaful's competitiveness. Fourth, to evaluate whether the Takaful insurance industry can achieve long-term competitive market structure, it is beneficial to compare the competitiveness of general Takaful and family Takaful to ensure that both business structures are competing in a healthy manner despite the fact that almost two-thirds of the Takaful business is contributed by family Takaful. Lastly, this paper will examine the effects of efficiency on the competitiveness of Takaful insurance in Malaysia so that the managers of Takaful operators will be able to identify ways in which they can achieve efficiency at the same time as competing soundly with their peers; it will also provide information to the regulators regarding whether any regulatory measures ought to be taken to strike a balance between consumer benefits and the sustainability of Takaful insurance.

Collectively, the present study contributes significantly to the finance literature, particularly the literature on Islamic finance, by conducting efficiency and competitiveness research on Islamic insurance. Although a number of studies have examined the topics of efficiency and competitiveness, hardly any systematic research has been conducted on the Islamic insurance sector. We differentiate this study from previous studies by comparing the performance of family Takaful vs. general Takaful. Although many papers (Cummins et al., 2017; Biener, Eling, \& Jia, 2017) have investigated size as a possible common factor that influences the efficiency of insurers, our study provides accurate insight by looking at the effect of provision for outstanding claims on the efficiency and competitiveness of Takaful insurance. Spierdijk and Koning (2014) suggest that insurers should respond to outstanding claims by setting aside this provision has become a central subject in modern actuarial science. More interestingly, this paper examines the impact of efficiency on the competitiveness of Takaful insurers by attempting to provide novel research on the insurance sector. This issue has been studied in the banking sector by Andries and Capraru (2014), who suggest that increasing the efficiency of banks will increase competition, but Sufian (2011) and Apergis and Polemis (2016) conclude that greater efficiency of banks will decrease competition, describing mixed results in the banking industry. Thus, it is appropriate to explore this issue with respect to the Takaful industry.

The remainder of the present paper is organised as follows. In the next section, explanations of the background of Takaful in Malaysia are provided, followed by section 2, which contains a review of the relevant literature. Section 3 explains the data and research methodology used in this work. Section 4 describes the data and discusses the results. Finally, section 5 includes a summary of the main findings and their policy implications.

\section{Literature review}

\subsection{Efficiency}

The objective of the firm is to maximise profits by minimising costs and maximising revenues, conditional on the existing technology. This traditional microeconomic theory is complemented by the modern frontier efficiency analysis that explains the failure of optimisation is due to the failure of the firm to achieve efficiency (Cummins \& Weiss, 2013). The fundamental idea of efficiency analysis is to separate production units that perform well from 
those that perform poorly. This is made by approximating "best practice" efficient frontiers consisting of the dominant firms in an industry and comparing all firms in the industry to the frontiers. Charnes, Cooper and Rhodes (1978) developed Data Envelopment Analysis (DEA) to evaluate efficiency activities of non-profit bodies' participation in public programs. Later, DEA is expanded to evaluate the efficiency level in financial industries such as banks by Aktan and Masood (2010) and insurance firms by Eling and Schaper (2017). To be fully technical efficient, firm must operate on the best production frontier by producing maximum possible output from a set of resource inputs, i.e., they must be pure technically efficient and scale efficient. Cummins, Weiss, Xie and Zi (2010) and Biener et al. (2017) described that the capability of the firm to avoid waste by generating as much production as input resources allow refers to technical efficiency. Two components of technical efficiency are pure technical efficiency and scale efficiency. Pure technical efficiency refers to the proportion by which the firm could minimise its input resources by employing the best technology. Scale efficiency is the proportional reduction if the firm achieves constant returns to scale (CRS). Operating with CRS is the ultimate objective of firms because it allows them to avoid waste and operating at the optimal scale (Kumar, Charles, \& Mishra, 2016).

The insurance industry encounters many challenges, such as solvency risks, a shifting regulatory environment and competition. Determining the efficiency of the insurance industry is clearly imperative in identifying how insurers will respond to these challenges by recognising the related input and output factors. Inefficiency and lags in claim settlement practices in insurance companies caused by escalating prices prompted a study by Cummins and Weiss in 1993 to measure the cost efficiency in the non-life insurance field. Later, Cummins and Xie (2013) and Biener et al. (2017) employed data envelopment analysis (DEA) developed by Charnes et al. (1978) in assessing the efficiency of insurance firms. This method does not impose any functional form on the data, allowing the method to use multiple inputs and outputs. The results of these studies show that firm size, ownership structure, mode of business and human capital are important factors affecting firm performance. Cummins and Weiss (1993) mentioned that claim settlement practices can cause inefficiency; later, Spierdijk and Koning (2014) suggested that insurers should respond to outstanding claims by setting aside this provision. This allows us to identify a gap in the literature and provides us with an opportunity to explore the impact of provision for outstanding claims on the efficiency of Takaful insurance.

The study of the efficiency of the Takaful insurance industry is relatively new. Kader, Adams, Hardwick and Kwon (2014) examined the link between cost efficiency and board composition in non-life Takaful insurance firms operating in 17 Islamic countries using panel data for 2004-2007; DEA was used to compute cost-efficiency scores, and a second-stage logit transformation regression model was then employed to test the influence of corporate characteristics on these efficiencies. The outcomes showed that the average level of cost efficiency in Takaful insurance markets mirrors the efficiency in developed non-life insurance markets. That study lays a foundation for further research on the Takaful insurance industry, which is poised to become one of the major emerging international markets for insurance over the next decade. Hence, considering that there has been high-level acknowledgement of the noteworthy prospects for Malaysia in Islamic finance at the global level, it is reasonable to study the efficiency of Takaful insurance in Malaysia. 


\subsection{Competition}

The Panzar-Rosse method is a non-structural approach, which was developed by Panzar and Rosse (1987). The study of competition using the Panzar-Rosse model is rather new and recently this model is used to study the competitiveness level in the financial institution by Aktan and Masood (2010) and Apergis and Polemis (2016). A limited number of studies have used this reduced form test to measure industry concentration, especially in the insurance industry. The absence of concentration will lead to the presence of an oligopolistic industry structure, whereby an industry is characterised as lacking in competition. This situation can be measured by the coefficients of the input variables in the Panzar-Rosse model. Previous research on the insurance market has shown that the efficiency of insurers tends to be poor and that competition between insurers is not strong (Bikker \& Leuvensteijn, 2008; Cummins et al., 2017). The competitive pressure on insurance firms has increased over the decades; hence, insurance firms are now faced with difficulties in adjusting their costs so as to operate more efficiently. Thus, these studies suggest that studies of competition that identify the market structure of Takaful insurance and the factors that influence the competition in this market are needed to comprehend the analysis of efficiency.

\subsection{Efficiency and competition}

The relationship between efficiency and competition in the financial industry is studied in the banking areas (see: Sufian, 2011; Andries \& Capraru, 2014; Apergis \& Polemis, 2016). The efficiency and competition hypothesis suggests that increases in efficiency lead to increases in competition. This is because when the firms are efficient and able to reduce the cost of operations will lead to higher profit. This will increases the creation or entry of a more viable competitor to participate in this industry. Unlike the banking industry, the literature on the nexus between efficiency and competitiveness of the insurance market appears scant. Recently, Jeng (2015) analysed the variation in competition in the Chinese insurance industry, Alhassan and Biekpe (2016) examined the competition and efficiency in the non-life insurance market in South Africa and Todorov (2016) assessed the competition in the Bulgarian insurance industry. Jeng (2015) suggests that although the local insurance industry still needs protection, the authorities may need to comply with pressure from the global insurance community, as domestic and foreign firms do not face an equally competitive environment. The authorities also need to face the reality that the inability of foreign firms to compete equally will affect the local market and jeopardise customers' welfare in the long run. Furthermore, despite the declining insurance industry concentration, the behaviour of the insurance firms does not exclude the hypothesis of monopoly or collusive oligopoly behaviour. Evidence is provided that the insurance market is still suffering from unsound competition, which creates problems that may require further action by the regulators (Todorov, 2016). Additionally, Alhassan and Biekpe (2016) who studied the impact of competition on the efficiency of insurance, recommend that to reduce high-profit inefficiency and maximise the earning potential of non-life insurers, regulatory authorities should seek to improve the competitive conditions as a means of strengthening managerial efforts to reduce resource misuse and waste. 
In this vein, the knowledge gained from studies of market competition in the insurance industry, which shows that the intervention of regulators is required to ensure both the customers' welfare and the efficiency of insurers in the long run, provides stronger justification for studying the impact of efficiency on competitiveness within the Takaful insurance industry in Malaysia with the goal of providing meaningful information to the regulators of Islamic finance.

To summarise the literature review, it is understood that a study of the competitiveness of insurance firms will take into account traditional studies on efficiency. Hence, the objective of analysing efficiency and competitiveness in the Takaful insurance industry is to remedy the gaps that have been discussed in the existing literature. Thus, the novel contribution of this paper is to identify the factors that influence the efficiency and competitiveness of Takaful insurance. Next, examining the relationship between efficiency and competitiveness in Takaful insurance is essential in providing evidence concerning the recognition and internalisation of the financial integration process by the Takaful insurance industry.

\section{Data and methodology}

This study will examine a total of 11 family Takaful operators and 8 general Takaful operators in Malaysia spanning the period from 2011 to 2015. Among the 11 family Takaful operators, three are purely Family Takaful operators, and the others are composite (general Takaful and family Takaful) operators. The composite insurers are required to conduct their life and general insurance businesses under separate licences. Hence, even when the two types of insurance are provided under the same company name, financial reporting on family Takaful and general Takaful must be separated. The firm-level data were collected from the annual reports of the Takaful operators.

\subsection{Efficiency}

To achieve the first objective, that is, to examine the factors that influence the efficiency of Takaful insurance in Malaysia, this study will conduct non-parametric frontier data envelopment analysis (DEA) in the first stage to obtain a DEA score. Then, in the second stage, panel regression will be employed with the DEA score as the dependent variable and the insurance firms' specific factors as the independent variables. The DEA approach with variable returns to scale (VRS) is used to identify the input-oriented technical efficiency of each Takaful operator. This approach can be explained through the use of decision-making units (DMUs). ${ }^{2}$ The value of the objective function at its optimum is inferred as a measure of the relative efficiency of the DMU, being estimated relative to all DMUs where each is represented as a

\footnotetext{
2 Charnes et al. (1978), Wang and Lu (2015) exchange rate volatility, interest rate volatility, and long-term loans in relation to capital and ownership structure. Technical efficient precedes a reduction in problem loans, concentration of the operating units and developing information technology and utilization of financial derivatives. This paper provides a theoretical rationale and conceptualizing risk factors with environmental uncertainty. The innovation variables are determinants of the bank efficiency on Basel III Accord. lu00a9 2015 Vilnius Gediminas Technical University (VGTU and Kumar et al. (2016) provide a comprehensive discussions on the computation of DEA.
} 
ratio of virtue output to input. The final efficiency value is always positive and is less than or equal to 1 . If the objective value of the maximised score is close to 1 , the DMU is interpreted as relatively efficient; otherwise, it is described as inefficient. Technical efficiency (TE) is separated into pure technical efficiency (PE) and scale efficiency (SE), where

$$
T E=P E \times S E \text { equivalent to } T E_{i, C R S}=T E_{i, V R S} \times S E_{i} .
$$

Charnes et al. (1978) suggested CCR model that there was no relationship between efficiency and scale of operation with the assumption at constant return to scale (CRS) frontier. Later, the CCR model was expanded by Banker, Charnes and Cooper (1984) to examine the efficiency of DMUs characterised by variable return to scale (VRS) which is known as BCC model. The use of the CCR model when not all firms are operating at the optimal scale, will lead to the computations of TE confounded by SE. The measurement of TE devoid of these SE effects could be performed by BBC model. By performing both a CRS and a VRS DEA for the same data, the difference in the two TE scores for a particular firm is the scale inefficiency. PE is the capability of managers to utilise firms' given inputs which is the measurement of TE devoid of the SE consequences. SE is the exploiting scale economies by operating at a point where the production frontier displays CRS.

Cummins et al. (2010), and Biener et al. $(2016,2017)$ elaborated that inputs for insurers are generally consist of labour, business services and financial capital. Thus, we classify our input variables into three groups namely labour and business services, debt capital and equity capital. The principal services provided by insurers are risk-pooling and risk bearing services, financial intermediaries and services relating to insured losses. To capture for riskpooling and risk bearing services, we use net contribution income as an output variable due to the Takaful operators collect contribution from the consumers and engage in risk sharing through pooling. In keeping with the roles as financial intermediaries, the net investment income is the output variable as the results of utilising the funds from policyholders and invest the funds in financial assets. Claims loss as an output variable to provide services to losses due to this compensation is allocated to the claims payments for the losses incurred by the policyholders. The input variables, input prices and output variables used in this study are explained in Table 1.

In the second stage of the panel regression which is commonly used by the literature to examine the factors that influence efficiency (see: Cummins \& Xie, 2013; Eling \& Schaper, 2017), the equation used would be:

$$
\ln D E A_{i t}=\ln \text { Turnover }_{i t}+\ln \text { Size }_{i t}+\ln \text { Provclaims }_{i t}+\varepsilon,
$$

where Turnover $=$ Net Contribution Income/Total Assets; Size $=$ Total Assets; Provclaims $=$ Provision for Outstanding Claims.

Turnover is expected to have a positive relationship to efficiency because the higher the contributions received by the Takaful operators, the more likely it is that they will have sufficient funds to spend on their input efficiently. Size is expected to have a positive relationship to efficiency because the greater the operators' market shares in the Takaful insurance, they more readily they can gain the confidence of many customers, thus maximising their outputs with the given resources. Using random data from Takaful operators from 17 Islamic 
countries, Kader et al. (2014) found that size has positive impacts on cost, allocative, technical, pure technical and scale efficiency due to majority of Takaful operators in the sample are small to medium-sized by international standards that have plenty rooms to improve efficiency by increasing size. However, findings from Alhassan and Biekpe (2016) concluded that size has negative impacts on technical efficiency and pure technical efficiency as the firms are facing difficulties in monitoring and controlling as firms expand larger. The impacts of size on technical efficiency and cost efficiency are positive in European life insurance industry as suggested by Eling and Schaper (2017) that size expansion tends to improve efficiency. The expected impact of the provision for outstanding claims factor on efficiency is uncertain. If the operators reserve sufficient provision funds, they are able to pay claims promptly and efficiently to the policyholders once the investigation and claims documentation process is completed; hence, the relationship is positive. On the other hand, if too large a proportion of the provision for outstanding claims is reserved, it will tighten the operators' funds and restrict other input expenses that are equally important in generating output; in this case, it will cause inefficiency, creating a negative relationship.

Table 1. Input and output variables

\begin{tabular}{|l|l|}
\hline \multicolumn{2}{|c|}{ Input } \\
\hline \multicolumn{1}{|c|}{ Variable } & \multicolumn{1}{c|}{ Proxy/Explanation } \\
\hline $\begin{array}{l}\text { Labour and } \\
\text { business ser- } \\
\text { vices }\end{array}$ & $\begin{array}{l}\text { = Management expenses + Other Outgo } \\
\text { Because the number of employees is not disclosed, common practice is to aggre- } \\
\text { gate labour and business services into one category labelled "operating expenses" } \\
\text { (Eling \& Schaper, 2017) }\end{array}$ \\
\hline Debt Capital & $\begin{array}{l}\text { = Government Islamic Papers } \\
\text { This is the amount invested in Islamic bonds issued by the Malaysian government } \\
\text { = Islamic Securities and Equities } \\
\text { This is the amount invested in Islamic - related securities in the market }\end{array}$ \\
\hline \multicolumn{1}{|c|}{ Vquity Capiable } & \multicolumn{1}{c|}{ Output } \\
\hline $\begin{array}{l}\text { Net Contribu- } \\
\text { tion Income }\end{array}$ & $\begin{array}{l}\text { = Net Contribution Income } \\
\text { Takaful operators receive funds from their customers as a result of operating }\end{array}$ \\
\hline $\begin{array}{l}\text { Net Investment } \\
\text { Income }\end{array}$ & $\begin{array}{l}\text { = Net Investment Income } \\
\text { This comes from the collected contribution and is invested by Takaful operators } \\
\text { to generate income }\end{array}$ \\
\hline Claims loss & $\begin{array}{l}\text { = Claims payment } \\
\text { Payment for the claims that resulting from the risks of adverse claims experience }\end{array}$ \\
\hline
\end{tabular}

The second objective is to compare the efficiency of family Takaful with that of general Takaful. From the DEA scores obtained in the first stage, both parametric tests (t-test) and non-parametric tests (the Mann-Whitney and Kolmogorov-Smirnov tests) will be executed to determine whether there are any differences in efficiency between these two types of Takaful operators and to determine which segment is more efficient. 


\subsection{Competition}

The third objective is to examine the competitiveness. The Takaful market structure in Malaysia is identified using the Panzar-Rosse method. The revenue of the $i$ th firm of the Takaful operator at time $t$ is estimated using equation 3 and is explained in Table 2 .

$\ln R_{i t}=f\left(\ln P_{i t}, \ln Z_{i t}, \varepsilon_{t}\right)$ which can be illustrated in full equation (3) with details of the variables of interest to make it easier and have a better understanding of the model

$$
\begin{aligned}
& \ln \operatorname{Re} v_{i t}=\alpha_{0}+\alpha_{1} \ln p 1_{i t}+\alpha_{21 .} \ln p 2_{i t}+\ln p 3_{i t}+ \\
& \beta_{1} \ln \text { turnover }_{i t}+\beta_{2} \text { size }_{i t}+\beta_{3} \text { provclaims }_{i t}+\varepsilon_{i t},
\end{aligned}
$$

where $R e v_{i t}$ is the revenues, $P_{i t}$ represents the vector of factor prices (labour price denoted as $\mathrm{p} 1$, cost of claims denoted as $\mathrm{p} 2$, cost of commission denoted as $\mathrm{p} 3), Z_{i t}$ represents the firms' variables (turnover, size, provision for outstanding claims) affecting the function, and $\varepsilon_{t}$ is the error term.

The P-R H-statistics can be written as follows if firm i utilises $m$ inputs:

$$
H=\sum_{k=1}^{m} \frac{\partial R_{i t} / R_{i t}}{\partial w_{i t k} / w_{i t k}}=\sum_{k=1}^{m} \frac{\partial \ln R_{i t}}{\partial \ln w_{i t k}} .
$$

Hence, the sum of the elasticity of the reduced-form revenue corresponds to $H$ with respect to all the factor prices (sum of the coefficients for $\mathrm{p}_{1}, \mathrm{p}_{2}$ and $\mathrm{p}_{3}$ ). The $H$-statistics describe the percentage change in the equilibrium revenue resulting from a percent change in the price of all inputs employed by the firms. Panzar and Rosse (1987), Jeng (2015) and Alhassan and Biekpe (2017) explained that under monopoly market, a rise in input prices increases marginal cost which reduces equilibrium output and subsequently diminishes total revenues. Under perfect competition market, changes in input prices cause proportional changes in production cost and total revenues without influencing output levels. In the monopolistic competition market, changes in input prices result in more than proportionate change in revenues. $H$ is the summation for the coefficients of price variables computed by $\alpha_{1}+\alpha_{2}+\alpha_{3}$. For a monopoly, a perfectly colluding oligopoly and a homogeneous conjectural variations oligopoly, the value is $H<0$. Conversely, in a symmetric perfectly competitive market in long-term equilibrium, $H=1$. Finally, for a symmetric monopolistic competition market, $0<H<1 .^{3}$ One can calculate the P-R H-statistic using the return on assets (ROA) as the dependent variable: a value of $H=0$ would prove equilibrium. Aktan and Masood (2010)and Coccorese (2012) suggests considering (1+ROA) as the dependent variable to avoid taking the natural logarithm of a negative value. Therefore, to test for long run equilibrium in our study, we replaced the revenues with ROA as the dependent variable, where it is computed by 1 plus the ratio of the net contribution income and net investment income to total assets. ${ }^{4}$

\footnotetext{
${ }^{3}$ Detailed assumptions on P-R model are well discussed by technique Panzar and Rosse (1987); Aktan and Masood (2010).

${ }^{4}$ A vital element of the $\mathrm{H}$-statistics being obtained must be undertaken on observations that are in long run equilibrium. $H=0$ specifies equilibrium and $H<0$ specifies disequilibrium. This is because, in equilibrium, the rates of return should not be statistically correlated with input prices. (for further derivation of the H-statistic, see Bikker and Haaf (2002) and Jeng (2015).
} 
Table 2. Variables for the Panzar-Rosse competitiveness study

\begin{tabular}{|l|l|l|l|}
\hline \multicolumn{2}{|c|}{ Variable (Name) } & \multicolumn{1}{c|}{ Proxy/Explanation } & \multicolumn{1}{c|}{ Studied by } \\
\hline R & ln (revenue), ln Rev & $\begin{array}{l}\text { = Net contribution income + } \\
\text { net investment income } \\
\text { Takaful operator earns revenue } \\
\text { through the contribution } \\
\text { received and returns from } \\
\text { investments }\end{array}$ & $\begin{array}{l}\text { Jeng (2015); } \\
\text { Alhassan and Biekpe } \\
\text { (2016) }\end{array}$ \\
\hline p1 & ln (labour price), ln p1 & $\begin{array}{l}\text { Other Outgo)/Total Assets } \\
\text { Proxy for the unit price of } \\
\text { labour administration }\end{array}$ & $\begin{array}{l}\text { Alhassan and Biekpe } \\
(2016)\end{array}$ \\
\hline p2 & ln (cost of claims), ln p2 & $\begin{array}{l}\text { = Net Claims Paid/Total Assets } \\
\text { Proxy for the price of debt } \\
\text { capital }\end{array}$ & Coccorese (2012) \\
\hline p3 & $\begin{array}{l}\text { ln (cost of commission), ln } \\
\text { p3 }\end{array}$ & $\begin{array}{l}\text { Commission Paid/Total Assets } \\
\text { Proxy for the price of equity } \\
\text { capital }\end{array}$ & Todorov (2016) \\
\hline Z1 & ln (turnover), ln Turnover & $\begin{array}{l}\text { Net contribution income/Total } \\
\text { Assets }\end{array}$ & Coccorese (2012) \\
\hline Z2 & ln (size), ln Size & $\begin{array}{l}\text { Total Assets } \\
\text { Proxy for the size }\end{array}$ & $\begin{array}{l}\text { Coccorese (2012); } \\
\text { Jeng (2015) }\end{array}$ \\
\hline Z3 & $\begin{array}{l}\text { ln (provision outstanding } \\
\text { claim), ln Provclaims }\end{array}$ & $\begin{array}{l}\text { Uncertainty of outstanding } \\
\text { claims and unexpired risks }\end{array}$ & - \\
\hline
\end{tabular}

For the fourth objective, which is to compare the competitiveness of general Takaful with that of family Takaful, the method is similar to the method used to achieve the third objective, as mentioned above. The only difference is that the sample is divided into two segments, one segment containing all the family Takaful operators and another segment containing all the general Takaful operators.

\subsection{Efficiency and competition}

The fifth objective is to examine the effects of efficiency on the competitiveness of Takaful insurance in Malaysia. Here, the DEA efficiency score is included among the independent variables and is re-estimated using the Panzar-Rosse model. Thus, by extending equation (3), we have $\ln R_{i t}=f\left(\ln P_{i t}, \ln Z_{i t}, \ln D E A_{i t}, \varepsilon_{t}\right)$ which can be demonstrated in full equation (5)

$$
\begin{aligned}
& \ln \operatorname{Re} v_{i t}=\alpha_{0}+\alpha_{1} \ln p 1_{i t}+\alpha_{21 .} \ln p 2_{i t}+\alpha_{31 .} \ln p 3_{i t}+ \\
& \beta_{1} \ln \text { turnover }_{i t}+\beta_{2} \text { size }_{i t}+\beta_{3} \text { provclaims }_{i t}+\theta_{1} D E A_{i t}+\varepsilon_{i t}
\end{aligned}
$$

where $P_{i t}$ represents the vector of factor prices (labour price, cost of claims, cost of commission), $Z_{i t}$ represents the firms' variables (turnover, size, provision for outstanding claims) that affect their function, $D E A_{i t}$ represents the efficiency score, and $\varepsilon_{t}$ is the error term. 


\section{Data analysis and interpretation}

\subsection{Efficiency}

Table 3 presents the results for technical efficiency (TE), which is decomposed into pure technical efficiency (PE) and scale efficiency (SE) that have been discussed in section 3 Data and Methodology section. From the observations made for the years 2011 to 2015, the mean TE of the Malaysian Takaful sector ranges from a low of $76.2 \%$ in 2014 to a high of $87 \%$ in 2015. This shows that the Takaful sector is operating at actual cost and above the minimum costs level, which ranges from 13\% to 23.8\%. Furthermore, from 2013 onwards, the mean PE scores are higher than the SE scores for all the sample years. Thus, in essence, scale inefficiency has a greater impact than pure technical inefficiency in the case of the Malaysian Takaful insurance sector. Additionally, the difference in efficiency of family Takaful and general Takaful operators does not seem to change significantly from year to year. This is because, based on the results of the parametric t-test and the non-parametric tests (MannWhitney and Kruskall-Wallis tests) as proposed by Sufian (2011), the results for TE, PE and SE in 2012 and 2013 do not show significant differences between family Takaful and general Takaful. For the 2011 data, the Mann-Whitney test shows a significant difference for mean SE between family Takaful and general Takaful; family Takaful is scale-efficient at $100 \%$, but general Takaful is relatively inefficient, with a mean SE of 91.9\%. Similar to the year 2015, there is a significant difference in TE between family Takaful and general Takaful; family Takaful postulates a higher mean TE than general Takaful. This is due to the higher mean PE of family Takaful compared to general Takaful and suggests that family Takaful is more efficient than general Takaful.

Overall, Takaful operators exhibit an average TE of $81.2 \%$; family Takaful exhibits an average TE of $85.7 \%$, and general Takaful reports an average TE of $74.9 \%$. These findings suggest that family Takaful is more efficient than general Takaful. These results provide an answer to the question of why the family Takaful sector is dominant in Malaysia, whereas most countries tend to focus on the general Takaful sector. For Takaful operators, the average $\mathrm{PE}$ is $91.6 \%$ and the average SE is $88.6 \%$. These results seem to indicate that the technical inefficiency of Takaful insurance in Malaysia is greatly affected by the scale of operations rather than by inefficient utilisation of resources due to managerial practices.

Table 3. Summary of parametric and non-parametric test results

\begin{tabular}{|c|c|c|c|c|c|c|}
\hline & & $\begin{array}{c}\text { Para- } \\
\text { metric } \\
\text { test }\end{array}$ & \multicolumn{5}{|c|}{ Non-parametric test } \\
\hline Individual test & & $\mathrm{t}$-test & & & Mann-Whitney test & Kruskall-Wallis \\
\hline Hypothesis & & & & & $\begin{array}{c}\text { Median general Takaful }= \\
\text { Median family Takaful }\end{array}$ & $\begin{array}{c}\text { Equality of } \\
\text { population test }\end{array}$ \\
\hline Test statistics & & & \multicolumn{2}{|c|}{$\mathrm{t}($ Prb $>0)$} & $\mathrm{z}($ Prb $>\mathrm{z})$ & Chi (Prb $>$ Chi) \\
\hline & & Mean & $\mathrm{t}$ & $\begin{array}{c}\text { Mean } \\
\text { rank }\end{array}$ & $\mathrm{z}$ & Chi sqr \\
\hline 1 & 2 & 3 & 4 & 5 & 6 & 7 \\
\hline
\end{tabular}


Continued Table 3

\begin{tabular}{|c|c|c|c|c|c|c|}
\hline & 2 & 3 & 4 & 5 & 6 & 7 \\
\hline \multicolumn{7}{|c|}{ Year 2011} \\
\hline \multirow{3}{*}{$\mathrm{TE}$} & FT & 0.909 & 1.093 & 11.18 & -1.240 & -0.807 \\
\hline & GT & 0.785 & & 8.38 & & \\
\hline & All & 0.857 & & & & \\
\hline \multirow{3}{*}{ PE } & FT & 0.909 & 0.505 & 10.18 & -0.213 & -0.538 \\
\hline & GT & 0.855 & & 9.75 & & \\
\hline & All & 0.886 & & & & \\
\hline \multirow{3}{*}{ SE } & FT & 1.000 & 1.451 & 12 & $-2.547^{\star *}$ & -1.076 \\
\hline & GT & 0.919 & & 7.25 & & \\
\hline & All & 0.966 & & & & \\
\hline \multicolumn{7}{|c|}{ Year 2012} \\
\hline \multirow{3}{*}{$\mathrm{TE}$} & FT & 0.808 & 0.346 & 10.41 & -0.386 & 0.538 \\
\hline & GT & 0.771 & & 9.44 & & \\
\hline & All & 0.792 & & & & \\
\hline \multirow{3}{*}{ PE } & FT & 0.892 & 0.204 & 9.55 & -0.477 & 0.44 \\
\hline & GT & 0.873 & & 10.63 & & \\
\hline & All & 0.884 & & & & \\
\hline \multirow{3}{*}{ SE } & FT & 0.911 & 0.57 & 11.09 & -1.103 & 0.758 \\
\hline & GT & 0.871 & & 8.5 & & \\
\hline & All & 0.894 & & & & \\
\hline \multicolumn{7}{|c|}{ Year 2013} \\
\hline \multirow{3}{*}{$\mathrm{TE}$} & FT & 0.753 & 0.246 & 10.86 & -0.314 & 0.427 \\
\hline & GT & 0.823 & & 10.06 & & \\
\hline & All & 0.781 & & & & \\
\hline \multirow{3}{*}{ PE } & FT & 0.966 & 0.608 & 11.18 & -0.749 & 0.337 \\
\hline & GT & 0.944 & & 9.67 & & \\
\hline & All & 0.957 & & & & \\
\hline \multirow{3}{*}{ SE } & FT & 0.777 & -0.062 & 10.59 & -0.08 & 0.382 \\
\hline & GT & 0.871 & & 10.39 & & \\
\hline & All & 0.815 & & & & \\
\hline \multicolumn{7}{|c|}{ Year 2014} \\
\hline \multirow{3}{*}{$\mathrm{TE}$} & FT & 0.880 & $2.692^{\star *}$ & 13.04 & $-2.431^{\star *}$ & 1.369 \\
\hline & GT & 0.585 & & 6.69 & & \\
\hline & All & 0.762 & & & & \\
\hline \multirow{3}{*}{$\mathrm{PE}$} & FT & 0.940 & 0.551 & 11.04 & -0.618 & 0.456 \\
\hline & GT & 0.860 & & 9.69 & & \\
\hline & All & 0.908 & & & & \\
\hline
\end{tabular}


End of Table 3

\begin{tabular}{|c|c|c|c|c|c|c|}
\hline 1 & 2 & 3 & 4 & 5 & 6 & 7 \\
\hline \multirow{3}{*}{ SE } & FT & 0.921 & $2.096^{*}$ & 12.46 & $-2.046^{\star *}$ & 1.095 \\
\hline & GT & 0.700 & & 7.56 & & \\
\hline & All & 0.833 & & & & \\
\hline \multicolumn{7}{|l|}{ Year 2015} \\
\hline \multirow[t]{3}{*}{$\mathrm{TE}$} & FT & 0.936 & $2.113^{\star *}$ & 11.59 & -1.563 & 1.149 \\
\hline & GT & 0.779 & & 7.81 & & \\
\hline & All & 0.870 & & & & \\
\hline \multirow[t]{3}{*}{$\mathrm{PE}$} & FT & 1.000 & $2.464^{* *}$ & 12 & $-2.547^{\star \star}$ & 1.076 \\
\hline & GT & 0.866 & & 7.25 & & \\
\hline & All & 0.944 & & & & \\
\hline \multirow[t]{3}{*}{ SE } & FT & 0.936 & 0.511 & 10.14 & -0.143 & 0.342 \\
\hline & GT & 0.902 & & 9.81 & & \\
\hline & All & 0.922 & & & & \\
\hline \multicolumn{7}{|l|}{ All Years } \\
\hline \multirow[t]{3}{*}{$\mathrm{TE}$} & FT & 0.857 & $2.738^{\star * *}$ & 55.12 & $-2.646^{\star * *}$ & $1.458^{\star \star}$ \\
\hline & GT & 0.749 & & 40.65 & & \\
\hline & All & 0.812 & & & & \\
\hline \multirow[t]{3}{*}{$\mathrm{PE}$} & FT & 0.941 & 1.576 & 51.65 & -1.373 & 0.848 \\
\hline & GT & 0.880 & & 45.38 & & \\
\hline & All & 0.916 & & & & \\
\hline \multirow[t]{3}{*}{ SE } & FT & 0.909 & $2.085^{\star *}$ & 54.3 & $-2.464^{* *}$ & $1.221^{\star}$ \\
\hline & GT & 0.853 & & 41.76 & & \\
\hline & All & 0.886 & & & & \\
\hline
\end{tabular}

Note: FT = family Takaful; GT = general Takaful; All = family Takaful and general Takaful; TE = technical efficiency; $\mathrm{PE}=$ pure technical efficiency; $\mathrm{SE}=$ scale efficiency; ${ }^{* \star}$ indicates significance at the 0.05 probability level; ${ }^{* * *}$ indicates significance at the 0.01 probability level.

Table 4 shows the panel regression results examining the firm-level factors that influence the efficiency of the Takaful insurance sector. ${ }^{5}$ Provision for outstanding claims on the efficiency level, one of our main focuses in this study, are shown to significantly influence the TE and SE of all the Takaful operators. From Model 3, provision for outstanding claims negatively and significantly affects the scale efficiency, suggesting that the more provision is allocated for outstanding for claims, the less efficient Takaful operators are in their utilisation of resources to maximise outputs. Thus, an increase in provision for outstanding claims will cause Takaful operators to be technically inefficient. This inefficiency is supported by the result obtained with Model 1, which shows that a $1 \%$ increase in provision for outstanding claims reduces the technical efficiency of Takaful operators by $4.01 \%$. The impact of provision for outstanding claims in Model 2 is not statistically significant, indicating that this

\footnotetext{
5 Following the various tests as recommended by Gujarati and Porter (2009) to choose the best model, our results support that pooled ordinary least square is the most appropriate model.
} 
factor will not cause managerial inefficiency but further supporting the idea that provision for outstanding claims causes the Takaful operators to be scale-inefficient, thus leading to technical inefficiency. Generally, size and turnover do not seem to significantly influence the efficiency of Takaful operators. The findings suggest that the Takaful operators have to be cautious in estimating the amount of provision to allocate to outstanding claims despite the fact that their businesses have large total assets and experience reasonable turnover. The results support the conclusions of Spierdijk and Koning (2014) that estimating provision for outstanding claims has become a central subject in modern actuarial science; thus, actuaries working in the Takaful insurance business need to ensure that their provision for outstanding claims are based on robust and rigorous estimations.

Table 4. Panel regressions of factors that impact efficiency

\begin{tabular}{|c|c|c|c|c|c|c|c|c|c|}
\hline & \multicolumn{3}{|c|}{ All Takaful operators } & \multicolumn{3}{|c|}{ Family Takaful operators } & \multicolumn{3}{|c|}{ General Takaful operators } \\
\hline & Model 1 & Model 2 & Model 3 & Model 4 & Model 5 & Model 6 & $\begin{array}{c}\text { Model } \\
7\end{array}$ & Model 8 & Model 9 \\
\hline 字 & $\ln \mathrm{TE}$ & $\ln \mathrm{PE}$ & $\ln \mathrm{SE}$ & $\ln \mathrm{TE}$ & $\ln \mathrm{PE}$ & $\ln \mathrm{SE}$ & $\ln \mathrm{TE}$ & $\ln \mathrm{PE}$ & $\ln \mathrm{SE}$ \\
\hline 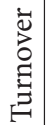 & 0.0542 & 0.0184 & 0.0358 & 0.0346 & -0.0012 & 0.0358 & $0.284^{*}$ & $0.225^{\star *}$ & 0.0589 \\
\hline$\Xi$ & $(0.0413)$ & $(0.0269)$ & $(0.0321)$ & $(0.0365)$ & $(0.0231)$ & $(0.0265)$ & $(0.144)$ & $(0.0873)$ & $(0.123)$ \\
\hline 芯 & 0.0310 & 0.0232 & 0.0078 & 0.0129 & -0.00086 & 0.0138 & $0.253^{*}$ & $0.289^{* * *}$ & -0.0357 \\
\hline$=$ & $(0.0230)$ & $(0.0150)$ & $(0.0179)$ & $(0.0291)$ & $(0.0184)$ & $(0.0211)$ & $(0.149)$ & $(0.0904)$ & $(0.127)$ \\
\hline 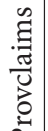 & $-0.0401^{\star * *}$ & -0.0099 & $-0.0302^{\star * *}$ & -0.0175 & 0.0039 & $-0.0214^{\star}$ & $-0.245^{\star}$ & $-0.222^{\star * *}$ & -0.0223 \\
\hline$\Xi$ & $(0.0141)$ & $(0.0092)$ & $(0.0110)$ & $(0.0158)$ & $(0.0100)$ & $(0.0115)$ & $(0.125)$ & $(0.0759)$ & $(0.107)$ \\
\hline $\begin{array}{l}\vec{\Xi} \\
\overrightarrow{\tilde{J}} \\
\overrightarrow{0}\end{array}$ & -0.1540 & -0.3820 & 0.2270 & -0.133 & -0.1180 & -0.0157 & -0.604 & $-1.507^{\star * *}$ & 0.904 \\
\hline$\cup$ & $(0.404)$ & $(0.2630)$ & $(0.3140)$ & $(0.486)$ & $(0.307)$ & $(0.352)$ & $(0.896)$ & $(0.545)$ & $(0.767)$ \\
\hline 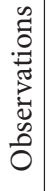 & 97 & 97 & 97 & 57 & 57 & 57 & 40 & 40 & 40 \\
\hline 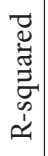 & 0.094 & 0.029 & 0.095 & 0.041 & 0.004 & 0.099 & 0.168 & 0.277 & 0.092 \\
\hline
\end{tabular}

Note: ${ }^{*},{ }^{* *}$, and ${ }^{* *}$ indicate significance at the $0.10,0.05$, and 0.01 probability levels, respectively. 
Moving to the results for family Takaful obtained from Models 4 to 6 in Table 4, none of the firm-specific factors seem to be significantly related to the efficiency level, with the exception of provision for outstanding claims in Model 6; there, that factor negatively and statistically significantly influences the scale efficiency of family Takaful in Malaysia at the $10 \%$ level. However, this will not lead to technical inefficiency in the family Takaful. The results suggest that there could be other macroeconomic factors, such as population, that might influence the efficiency of family Takaful. This is because, as reported in the Malaysian Takafu 1Association Annual Report (2015), the growth prospects for the family Takaful sector are likely to remain stable due to the great size of the Islamic population in Malaysia.

Next, Models 7 to 9 in Table 4 are used to determine the firm-specific factors that influence general Takaful. All three factors, namely, turnover, size and provision for outstanding claims, seem to significantly influence the pure technical efficiency of general Takaful in Malaysia, as illustrated in Model 8. Size and turnover positively affect the pure technical efficiency, likely because the larger the firm, the greater its ability to generate contribution income, making it possible for the managerial staff to perform more efficiently. This may suggest that the receipt of benefits such as salary increments or other fringe benefits by managers will motivate them to work more efficiently. Hence, this will help the general Takaful in Malaysia achieve overall technical efficiency. This explanation is supported by Model 9, as the specific firm-level factors being studied do not have significant effects on scale efficiency; instead, these factors affect the pure technical efficiency and finally influence the overall technical efficiency.

To summarise the findings in line with the first objective, among the effects of three factors on efficiency, provision of outstanding claims postulates negative impacts to the technical efficiency of all the Takaful operators and contributes to the novelty of this research as it has yet to be examined in the past literature. Turnover and size are positively affecting the pure technical efficiency of general Takaful operators. This is consistent with the findings by Kader et al. (2014) that found positive and significant relationship of size on technical and scale efficiency in Takaful operators. However, the results do not support the discoveries by Biener et al. (2016) that described negative relationship of size on conventional life and general insurers. This reason might be due to Takaful operators are less developed than conventional insurers that require the expansion of Takaful operators to improve efficiency. For the second objective, this research concludes that family Takaful operators are more efficient than general Takaful operators. This is to complement the existing studies that examined the efficiency of the whole Takaful industry but did not investigate the differences between family Takaful and general Takaful (Kader et al., 2014).

\subsection{Competition}

The Panzar-Rosse (P-R) method will be employed to assess the competitiveness of Takaful operators in Malaysia. The competitiveness results are presented in Table 5. The results derived from all the Takaful insurers are presented in Panel A. The evidence suggests that the Takaful insurance industry in Malaysia is a monopoly market. This is because among the 6 models, the $\mathrm{H}$-statistics of 4 models (a1, a3, a4, and a6) are significantly less than 0 , but 
those of Models a 2 and a5 are not statistically significantly greater than 0 . The models are also valid because when the dependent variable is replaced by ROA, the F-statistics are unable to reject the null hypothesis (Ho: market is in the equilibrium condition). Jeng (2015) suggests that insurers in developing countries are still far from participating in a competitive market. Consistent with the findings of Jeng (2015), Malaysia is a developing country; thus, the Takaful insurance market suffers from a lack of competition. Since the market has a monopoly structure, it appears that there might be collusive behaviour in the Takaful insurance sector.

The cost of claims, p2, postulates positive significant impact on revenue. This could be because certain claims that have been paid to the claimants are considered to have fulfilled the firm's promise to share the risk. This will indirectly increase the customers' trust in Takaful insurance and support the Takaful product, leading to an increase in revenue. For the price of commissions, p3, Models a1, a3, a4 and a6 show a significant reduction in the revenue of Takaful insurance companies. This is consistent with the findings of Fah and Sin (2014) provider of financial services and risk transferor. These important roles have created strong demand for insurance products. Strong financial fundamentals combined with industry strength are vital for insurance-based companies to continuously do well in their business. This paper analyses the Earnings Response Coefficients (ERCs), in which the commissions paid to agents that assist the insurers in targeting sales are shown to play important roles in determining the firms' profits.

Turnover, which is proposed to have a positive relationship to revenue, indicates that the firms are utilising their total assets to generate higher revenue. The size control variable indicates a positive relationship with revenue, suggesting that Takaful insurers in Malaysia are operating at economies of scale. In Models a 2 and a4, provision for claims positively and significantly influence the revenue. Based on the results from competitiveness models and efficiency models, although provision for claims causes inefficiency for Takaful insurers, it can also help them generate higher revenue. This variable, which represents the total forecasted cost to the insurance firm, includes all claims that have occurred up to the end of the financial year regardless of whether or not the cases have been reported, and it excludes the amounts already paid in regard to the claims. Since it could be the case that not all accidents are reported to the insurance firms immediately following the events and that not all claims are paid immediately to the insured, this provision plays a major role in the insurance firm. Because sufficient provision for outstanding claims ensures the effectiveness of insurers in handling and satisfying their customers, it will increase the revenue of the Takaful operators.

Table 5. Panzar-Rosse results for competitive conditions in Takaful insurance in Malaysia

\begin{tabular}{|c|c|c|c|c|c|c|}
\hline Panel A: All & $(\mathrm{a} 1)$ & $(\mathrm{a} 2)$ & $(\mathrm{a} 3)$ & $(\mathrm{a} 4)$ & $(\mathrm{a} 5)$ & (a6) \\
\hline \multirow{2}{*}{$\ln \mathrm{p} 1$} & $-0.557^{* * *}$ & $0.602^{\star * *}$ & $0.162^{\star}$ & $-0.417^{* * *}$ & $0.602^{\star * *}$ & 0.0169 \\
\cline { 2 - 7 } & $(0.114)$ & $(0.0704)$ & $(0.0825)$ & $(0.103)$ & $(0.0708)$ & $(0.0822)$ \\
\hline \multirow{2}{*}{$\ln \mathrm{p} 2$} & $0.233^{* * *}$ & $0.168^{* *}$ & 0.122 & -0.00647 & $0.160^{* *}$ & $0.354^{* * *}$ \\
\cline { 2 - 7 } & $(0.0881)$ & $(0.0656)$ & $(0.108)$ & $(0.0879)$ & $(0.0740)$ & $(0.102)$ \\
\hline \multirow{2}{*}{$\ln \mathrm{p} 3$} & $-8.906^{* * *}$ & -0.0681 & $-10.02^{* * *}$ & $-10.57^{* * *}$ & -0.245 & $-8.407^{* * *}$ \\
\cline { 2 - 7 } & $(1.494)$ & $(1.303)$ & $(1.672)$ & $(1.332)$ & $(1.486)$ & $(1.776)$ \\
\hline
\end{tabular}


Continued Table 5

\begin{tabular}{|c|c|c|c|c|c|c|}
\hline Panel A: All & (a1) & (a2) & (a3) & (a4) & (a5) & (a6) \\
\hline \multirow{2}{*}{ ln Turnover } & $0.893^{* * *}$ & & & $0.906^{* * *}$ & & \\
\hline & $(0.142)$ & & & $(0.124)$ & & \\
\hline \multirow{2}{*}{$\ln$ Size } & & $0.947^{\star * *}$ & & & $0.935^{\star * *}$ & \\
\hline & & $(0.0782)$ & & & $(0.0911)$ & \\
\hline \multirow{2}{*}{ In Provclaims } & & & $0.244^{\star * *}$ & $0.251^{\star * *}$ & 0.0113 & \\
\hline & & & $(0.0570)$ & $(0.0453)$ & $(0.0450)$ & \\
\hline \multirow{2}{*}{ Constant } & $19.38^{\star * \star}$ & 1.841 & $15.86^{* * *}$ & $15.12^{* \star *}$ & 1.871 & $20.01^{* * *}$ \\
\hline & $(0.273)$ & $(1.513)$ & $(1.006)$ & $(0.807)$ & $(1.525)$ & $(0.303)$ \\
\hline Observations & 96 & 96 & 96 & 96 & 96 & 96 \\
\hline R-squared & 0.488 & 0.718 & 0.389 & 0.618 & 0.719 & 0.265 \\
\hline F-statistics & $21.65^{\star \star \star}$ & $58.04^{\star \star \star}$ & $14.48^{\star \star \star}$ & $29.09^{\star * *}$ & $45.97^{\star * *}$ & $11.07^{* * *}$ \\
\hline H-statistics & -9.23 & 0.70 & -9.74 & -10.99 & 0.52 & -8.03 \\
\hline (F-stat) $\mathrm{H}=1$ & $46.50^{\star * *}$ & 0.05 & $41.2^{\star * *}$ & $79.94^{\star * \star}$ & 0.10 & $26.00^{* *}$ \\
\hline (F-stat) $\mathrm{H}=0$ & $37.85^{\star \star \star}$ & 0.28 & $33.88^{\star * \star}$ & $67.17^{\star \star \star}$ & 0.12 & $20.56^{\star * *}$ \\
\hline $\begin{array}{l}\text { Market Struc- } \\
\text { ture }\end{array}$ & M & $\mathrm{MC}$ & M & M & $\mathrm{MC}$ & M \\
\hline (F-stat) $\mathrm{E}=0$ & 0.52 & 0.05 & 1.21 & 0.47 & 0.04 & 1.30 \\
\hline LR Equilibrium & $\mathrm{E}$ & $\mathrm{E}$ & $\mathrm{E}$ & $\mathrm{E}$ & $\mathrm{E}$ & $\mathrm{E}$ \\
\hline Panel B: FT & (b1) & (b2) & (b3) & (b4) & (b5) & (b6) \\
\hline \multirow{2}{*}{$\ln \mathrm{p} 1$} & $-0.479^{\star * *}$ & $0.270^{\star * *}$ & -0.142 & $-0.384^{* * *}$ & $0.247^{* *}$ & $-0.289^{\star *}$ \\
\hline & $(0.141)$ & $(0.0919)$ & $(0.0958)$ & $(0.108)$ & $(0.0953)$ & $(0.111)$ \\
\hline \multirow{2}{*}{$\ln \mathrm{p} 2$} & $0.288^{\star \star}$ & $0.302^{\star \star \star *}$ & $0.176^{\star}$ & 0.0111 & $0.271^{\star * *}$ & $0.393^{* * *}$ \\
\hline & $(0.112)$ & $(0.0650)$ & $(0.0949)$ & $(0.0962)$ & $(0.0734)$ & $(0.103)$ \\
\hline \multirow{2}{*}{$\ln \mathrm{p} 3$} & 2.454 & 0.03927 & 0.1427 & 0.1529 & 0.04016 & 0.2312 \\
\hline & $(16.50)$ & $(10.77)$ & $(14.09)$ & $(12.64)$ & $(10.79)$ & $(17.00)$ \\
\hline \multirow{2}{*}{ ln Turnover } & $0.422^{\star *}$ & & & $0.573^{* * *}$ & & \\
\hline & $(0.202)$ & & & $(0.155)$ & & \\
\hline \multirow{2}{*}{ ln Size } & & $0.773^{\star * *}$ & & & $0.705^{\star * *}$ & \\
\hline & & $(0.0838)$ & & & $(0.112)$ & \\
\hline \multirow{2}{*}{ In Provclaims } & & & $0.264^{* * *}$ & $0.291^{\star * *}$ & 0.0479 & \\
\hline & & & $(0.0515)$ & $(0.0468)$ & $(0.0520)$ & \\
\hline \multirow{2}{*}{ Constant } & $19.39^{\star * *}$ & $4.961^{\star * *}$ & $15.31^{\star * *}$ & $14.56^{\star * *}$ & $5.473^{\star \star \star}$ & $19.62^{* * *}$ \\
\hline & $(0.322)$ & $(1.600)$ & $(0.877)$ & $(0.813)$ & $(1.696)$ & $(0.312)$ \\
\hline Observations & 57 & 57 & 57 & 57 & 57 & 57 \\
\hline R-squared & 0.316 & 0.719 & 0.508 & 0.612 & 0.723 & 0.258 \\
\hline F-statistics & $6.01^{* * *}$ & $33.23^{* * *}$ & $13.42^{\star * *}$ & $16.07^{\star * *}$ & $26.68^{* * *}$ & $6.16^{* * *}$ \\
\hline H-statistics & 0.231 & 0.572 & 0.034 & -0.373 & 0.558 & 0.335 \\
\hline (F-stat) $\mathrm{H}=1$ & 2.01 & 0.11 & 0.90 & 1.22 & 0.11 & 1.72 \\
\hline
\end{tabular}


End of Table 5

\begin{tabular}{|c|c|c|c|c|c|c|}
\hline Panel B: FT & (b1) & (b2) & (b3) & (b4) & (b5) & (b6) \\
\hline (F-stat) $\mathrm{H}=0$ & 2.19 & 0.18 & 10.3 & 1.40 & 0.18 & 1.87 \\
\hline $\begin{array}{l}\text { Market } \\
\text { Structure }\end{array}$ & $\mathrm{MC}$ & $\mathrm{MC}$ & $\mathrm{MC}$ & M & $\mathrm{MC}$ & $\mathrm{MC}$ \\
\hline (F-stat) $\mathrm{E}=0$ & $5.64^{\star *}$ & $4.50^{* *}$ & $5.28^{* *}$ & $5.70^{\star *}$ & $4.46^{\star *}$ & $5.47^{\star *}$ \\
\hline LR Equilibrium & $\mathrm{D}$ & $\mathrm{D}$ & $\mathrm{D}$ & $\mathrm{D}$ & $\mathrm{D}$ & $\mathrm{D}$ \\
\hline Panel C: GT & & (c2) & (c3) & (c5) & & (c6) \\
\hline \multirow{2}{*}{$\ln \mathrm{p} 1$} & & $0.822^{* * *}$ & $0.707^{\star \star \star}$ & $0.821^{* * *}$ & & $0.378^{\star * *}$ \\
\hline & & $(0.110)$ & $(0.123)$ & $(0.112)$ & & $(0.125)$ \\
\hline \multirow{2}{*}{$\ln \mathrm{p} 2$} & & -0.0777 & -0.0994 & -0.0264 & & $1.006^{* * *}$ \\
\hline & & $(0.281)$ & $(0.353)$ & $(0.309)$ & & $(0.325)$ \\
\hline \multirow{2}{*}{$\ln \mathrm{p} 3$} & & 0.0279 & -2.114 & 0.0363 & & $-0.665^{\star \star}$ \\
\hline & & $(2.025)$ & $(2.219)$ & $(2.059)$ & & $(2.490)$ \\
\hline \multicolumn{7}{|l|}{ ln Turnover } \\
\hline & & & & & & \\
\hline \multirow{2}{*}{ ln Size } & & $1.140^{* * *}$ & & $1.276^{* * *}$ & & \\
\hline & & $(0.178)$ & & $(0.366)$ & & \\
\hline \multirow{2}{*}{ ln Provclaims } & & & $0.810^{\star \star *}$ & -0.132 & & \\
\hline & & & $(0.175)$ & $(0.310)$ & & \\
\hline \multirow{2}{*}{ Constant } & & -1.885 & 5.315 & -2.016 & $21.71^{\star * *}$ & \\
\hline & & (3.733) & (3.621) & $(3.790)$ & $(0.907)$ & \\
\hline Observations & & 40 & 40 & 40 & 40 & \\
\hline R-squared & & 0.696 & 0.589 & 0.698 & 0.339 & \\
\hline F-statistics & & $30.03^{\star * *}$ & $12.56^{\star * *}$ & $15.68^{\star * *}$ & $6.15^{\star \star *}$ & \\
\hline H-statistics & & 0.772 & -1.506 & 0.831 & 0.719 & \\
\hline (F-stat) $\mathrm{H}=1$ & & 0.00 & 1.35 & 0.01 & $6.30^{\star *}$ & \\
\hline (F-stat) $\mathrm{H}=0$ & & 0.27 & 0.49 & 0.01 & $6.30^{\star *}$ & \\
\hline $\begin{array}{l}\text { Market } \\
\text { Structure }\end{array}$ & & $\mathrm{MC}$ & M & MC & $\mathrm{MC}$ & \\
\hline (F-stat) $\mathrm{E}=0$ & & 0.33 & 0.35 & 0.19 & 0.04 & \\
\hline LR Equilibrium & & $\mathrm{E}$ & $\mathrm{E}$ & $\mathrm{E}$ & $\mathrm{E}$ & \\
\hline
\end{tabular}

Note: The dependent variable is $\ln \mathrm{Rev}$ as defined in Table $2 . \mathrm{LR}=\operatorname{long}$ run, $\mathrm{M}=$ monopoly, $\mathrm{MC}=$ monopolistic competition, $\mathrm{E}=$ equilibrium, $\mathrm{D}=$ disequilibrium; ${ }^{\star},{ }^{* \star}$ and ${ }^{* \star *}$ indicate significance at the $0.10,0.05$ and 0.01 probability levels, respectively.

Competitiveness among all the Takaful operators is postulated in Panel A of Table 5. When turnover is included in Model al and a4, the price of labour (p1) is negatively related to revenues. This proposes that when the Takaful operators are receiving a lot of contributions from the consumers, the wage paid for the labour has to be higher in order to provide good quality of service to the consumers, thus a lower amount of investment allocation is devoted and it will cause a drop in net investment income. This will lead to a reduction on 
revenues as it is contributed by net contribution income and net investment income. In Model a2 and a5, when the size of the Takaful operators is expanding, the cost of commission (p3) loses its significance to revenues. This recommends that the consumers are aware of the existence of Takaful operators and they are more prone to engage in the Takaful insurance products by self-awareness rather than the persuasive from agents. Cost of claim (p2) loses its significant power on revenues when provision for outstanding claims variable is included in Model a3 and a4. This is because the losses have occurred but yet to be paid out to the contributors of Takaful insurance, this amount is reserved by the Takaful operators, thus the cost of claims is lesser and its impact to the revenues become insignificant. All the models in Panel A propose that the market structure of Takaful operators in Malaysia is not perfect competition.

Panel B of Table 5 describes the competitiveness among family Takaful insurance operators. Similar to Panel A, the effects of labour price on revenues are negative when turnover is included in Model b1 and b4. It exhibits that family Takaful products require good quality of service from the staff, the Takaful operators will need to offer higher wage to the staff in order to motivate them to keep up with the good performance. However this situation will lower the investment income for the Takaful operators. The results indicate that monopolistic competition and monopoly structure among the family Takaful are not in long-term equilibrium, probably due to the higher demand of customers for family Takaful, a condition that could lead to disequilibrium.

The results in panel $\mathrm{C}$ show the competitiveness among general Takaful. Some models with missing results are not presented because these variables show multicollinearity in the models. The market structure of general Takaful is not perfectly competitive. It is worth emphasising that the price of labour is positively significant in all the models, unlike the results shown in panels $A$ and $B$, which yield different coefficient signs when labour price is estimated in different models. This suggests that general Takaful operators are willing to pay higher wages to hire professionals such as actuaries and adjusters. Actuaries play important roles in estimating and evaluating various types of risks, conditions and premium rates for Takaful policies, consistent with the findings of Williams et al. (2016) an opinion on reinsurance adequacy, an opinion on underwriting policy and contributing to the risk management system. Considerable documentation has been produced by the Prudential Regulation Authority (PRA), whom report that skilled actuaries are very much needed to ensure the continuing development of insurers. Furthermore, the roles of adjusters include investigating insurance claims by interviewing the claimant and witnesses, consulting police and inspecting property damage to determine the extent of the company's liability to ensure that there are no false claims that cause the insurers to pay unnecessary claims. However, the adjusters are encouraged to have knowledge of finance, economics, and Shariah principles along with sufficient dynamism and innovativeness to lead the industry forward. They play a crucial role in ensuring the sustainability of the Takaful industry.

To sum up, the third objective of our study is to examine the competitiveness of Takaful insurance industry in Malaysia and the results indicate that the market is not perfectly competitive. The outcome is consistent with the findings by Coccorese (2012), Jeng (2015), Alhassan and Biekpe $(2016,2017)$ that concluded the non-perfect competition market structure in 
the insurance industry that is beneficial to both firms and consumers. For the forth objective, our research suggests that both family Takaful and general Takaful are not in the perfect competition market structure. Although two-thirds of the Takaful business is contributed by family Takaful, family Takaful industry is not in long run equilibrium compared to the general Takaful industry which is in the long run equilibrium. This is similar to the findings by Jeng (2015) that proposed the conventional life insurers are in long run dis-equilibrium but general life insurers are in long run equilibrium that could be due to the life insurers are expanding.

\subsection{Efficiency and competition}

Table 6 illustrates the impact of efficiency on the competitiveness of Takaful insurance in Malaysia. When efficiency is included in the model, the effects of turnover, size and provision for outstanding claims exhibit the same results as reported in Panel A of Table 5. In this essence, irrespective whether the Takaful operators are efficient or not, higher wage is needed to encourage the staff to provide good quality of service to the participants in order to improve net contribution income but at the expense of net investment income, expansion of Takaful operators will enhance the participants' self-awareness to engage in Takaful insurance products that reduces the reliance on agents and provision for outstanding claims will lessen the real cost of claim. The result obtained with Model 1 demonstrates marginal negative significant influence at the $10 \%$ level. The plausible reason for the negative direction of efficiency to revenues could be due to the fact that the efficient Takaful operators are able to reduce their costs of operation, hence they are able to charge lower prices for the insurance products that leads to the reduction in revenues. ${ }^{6}$ The results shows that the greater the technical efficiency score, the lower the value of total revenues generated for Takaful insurance in Malaysia; this indicates that the Takaful operators with the highest inefficiency and those who incur the highest costs may be able to generate higher revenue than more cost-efficient Takaful operators. Furthermore, when the efficiency score is included in the competitiveness model, the H-statistics in Models 1-6, which are shown in Table 6, have higher values than those obtained using Models 1-6 in Panel A of Table 5 (without efficiency scores). This indicates that the market structure moves away from a monopoly structure when Takaful insurers are more efficient. These findings lead to the conclusion that "improving efficiency will increase competitiveness", which is consistent with the previous findings (Alhassan \& Biekpe, 2016; Apergis \& Polemis, 2016; Bikker \& Leuvensteijn, 2008). The authors of those studies also advise policymakers and economists that although improving the productive efficiency of firms boosts their international competitiveness, the role of competition in promoting efficiency in financial institutions is less intense because the insurance business involves high and excessive risks. The finding suggests that the use of more efficient planning will

\footnotetext{
6 For the efficient Takaful operators, they are better at insurance underwriting process compared to the inefficient Takaful operators in evaluating the risk and exposures of potential participants. Takaful underwriters decide how much the potential participants should be covered, the amount of premium to charge, or whether to reject the risk and decline to insure them. Therefore, the efficient Takaful operators are able to accept potential participants with appropriate risk and charge them lower premium. Nevertheless, policy volume would not increase tremendously as the efficient Takaful operators do not simply accept all the potential participants with inappropriate risks.
} 
determine the effectiveness of the firm's strategy and thereby reduce the costs of operations. Therefore, the Takaful insurance industry in Malaysia is an industry that carries high leverage associated with insolvency risks, and improvement in its efficiency is very much needed to enable operators to be more effective and competitive and to achieve sustainable growth.

Table 6. Relationship between efficiency and competitiveness

\begin{tabular}{|c|c|c|c|c|c|c|}
\hline & (1) & (2) & (3) & $(4)$ & (5) & (6) \\
\hline \multirow{2}{*}{ In DEA } & $-0.276^{\star}$ & 0.102 & 0.172 & 0.0614 & 0.120 & -0.152 \\
\hline & $(0.351)$ & $(0.258)$ & $(0.374)$ & $(0.309)$ & $(0.263)$ & $(0.401)$ \\
\hline \multirow{2}{*}{$\ln \mathrm{p} 1$} & $-0.456^{\star * *}$ & $0.549^{* * *}$ & $0.172^{\star \star}$ & $-0.323^{\star * *}$ & $0.549^{* * *}$ & 0.0267 \\
\hline & $(0.114)$ & $(0.0691)$ & $(0.0817)$ & $(0.101)$ & $(0.0695)$ & $(0.0819)$ \\
\hline \multirow{2}{*}{$\ln \mathrm{p} 2$} & $0.212^{\star *}$ & $0.200^{* * *}$ & 0.116 & -0.0276 & $0.187^{\star \star}$ & $0.337^{\star \star *}$ \\
\hline & $(0.0933)$ & $(0.0673)$ & $(0.107)$ & $(0.0911)$ & $(0.0757)$ & $(0.104)$ \\
\hline \multirow{2}{*}{$\ln \mathrm{p} 3$} & $-9.289^{* * *}$ & -0.376 & $-10.03^{\star * *}$ & $-10.82^{\star \star *}$ & -0.648 & $-8.615^{\star \star \star}$ \\
\hline & (1.573) & $(1.352)$ & $(1.670)$ & $(1.386)$ & $(1.524)$ & $(1.796)$ \\
\hline \multirow{2}{*}{ ln Turnover } & $0.774^{\star * *}$ & & & $0.809^{* * *}$ & & \\
\hline & $(0.142)$ & & & $(0.123)$ & & \\
\hline \multirow{2}{*}{$\ln$ Size } & & $0.885^{\star * *}$ & & & $0.867^{\star * *}$ & \\
\hline & & $(0.0765)$ & & & $(0.0896)$ & \\
\hline \multirow{2}{*}{ ln Provclaims } & & & $0.253^{* * *}$ & $0.269^{\star * *}$ & 0.0186 & \\
\hline & & & $(0.0575)$ & $(0.0476)$ & $(0.0472)$ & \\
\hline \multirow{2}{*}{ Constant } & $19.42^{\star * *}$ & $3.028^{* *}$ & $15.77^{* * *}$ & $14.93^{* * *}$ & $3.067^{* *}$ & $19.98^{* * *}$ \\
\hline & $(0.306)$ & $(1.480)$ & $(1.001)$ & $(0.837)$ & $(1.490)$ & $(0.330)$ \\
\hline Observations & 97 & 97 & 97 & 97 & 97 & 97 \\
\hline R-squared & 0.445 & 0.703 & 0.394 & 0.591 & 0.703 & 0.265 \\
\hline F-statistics & $14.61^{\star \star \star}$ & $42.98^{* * *}$ & $11.84^{\star * \star}$ & $21.66^{\star * *}$ & $35.51^{\star * *}$ & $8.28^{\star * *}$ \\
\hline H-statistics & -0.520 & 0.851 & 0.460 & -0.289 & 0.856 & 0.2117 \\
\hline (F-stat) $\mathrm{H}=1$ & $44.17^{\star * *}$ & 0.21 & $41.23^{* * *}$ & $75.66^{* * *}$ & 0.34 & $26.57^{* * *}$ \\
\hline (F-stat) $\mathrm{H}=0$ & $36.18^{\star * *}$ & 0.07 & $33.91^{\star * *}$ & $63.74^{\star \star *}$ & 0.01 & $21.14^{\star * *}$ \\
\hline Market Structure & $\mathrm{M}$ & $\mathrm{MC}$ & $\mathrm{MC}$ & $\mathrm{M}$ & $\mathrm{MC}$ & $\mathrm{MC}$ \\
\hline (F-stat) $\mathrm{E}=0$ & 0.58 & 0.04 & 1.57 & 0.51 & 0.06 & 1.62 \\
\hline LR Equilibrium & $\mathrm{E}$ & $\mathrm{E}$ & $\mathrm{E}$ & $\mathrm{E}$ & $\mathrm{E}$ & $\mathrm{E}$ \\
\hline
\end{tabular}

Note: The dependent variable is $\ln$ Rev as defined in Table 2. $\mathrm{LR}=$ long run, $\mathrm{M}=$ monopoly, $\mathrm{MC}=$ monopolistic competition, $\mathrm{E}=$ equilibrium, $\mathrm{D}=$ disequilibrium; ${ }^{*},{ }^{* *}$ and ${ }^{* * *}$ indicate significance at the $0.10,0.05$ and 0.01 probability levels, respectively.

Finally, the fifth objective is to examine the impacts of efficiency on the competitiveness on Takaful industry with the results that efficiency will enhance the competitiveness in reducing the impacts of non-competition. Similar to the findings by Bikker and Leuvensteijn (2008) who established that reduction in inefficiency would enhance competition which is advantageous to the insurers and protect the interests of consumers. However, inconsistent 
with the outcome by Alhassan and Biekpe (2017) that suggested smaller firms were usually less efficient but more competitive than larger firms. This study is also able to close the literature gap by Alhassan and Biekpe (2016) that examined the impact of competitiveness on efficiency that proposed the investigation on the reversed direction.

\section{Conclusions}

Being the first country in the world to implement a risk based capital framework in Malaysia presents an ideal opportunity to test the efficiencies and competitiveness in Malaysia due to the coexistence of a thriving Takaful insurance market and the less developed financial markets (Lee et al., 2018). Currently, the Malaysian Islamic finance brand name has surged drastically and has become a mainstream platform. There are noteworthy prospects for Islamic finance, particularly in Malaysia, which is one of the major Islamic financial hubs in the world. In this vein, the Malaysian Central Bank is attempting to set global standards for the effective regulation and supervision of Islamic finance so as to preserve financial stability in the Islamic financial system. These factors motivated the present paper to highlight the issues related to Takaful insurance in Malaysia. This paper contributes to the existing literature by examining the efficiency and competitiveness of the Takaful insurance industry in Malaysia.

Our study provides sharper insight by examining how provision for outstanding claims, which has become a central subject in modern actuarial science, influences the efficiency and competitiveness of Takaful insurance. The findings provide new evidence that provision for outstanding claims negatively and significantly affects scale efficiency, suggesting that the more provision is allocated for outstanding claims, the more it will cause Takaful operators to be inefficient in their utilisation of resources to maximise outputs. Nevertheless, higher provision for outstanding claims could help Takaful operators generate higher revenue because making sufficient provision for outstanding claims ensures the effectiveness of insurers in handling and satisfying customers so as to achieve shareholder wealth maximisation. Furthermore, the Takaful sector is operating at an actual cost that is above the minimum cost, suggesting that the operators are inefficient in operation; this is due to the scale of operations rather than to inefficient utilisation of resources due to managerial practice.

Overall, family Takaful is more efficient than general Takaful; this explains why two thirds of the Takaful business sector in Malaysia is contributed by family Takaful, whereas most countries focus on the general Takaful sector. This is a good strategy, as the Malaysian Takaful industry is benefitting from its comparative advantage in focusing on family Takaful. However, the evidence shows that the monopolistic market structure of family Takaful operators is not in long-term equilibrium. Thus, policymakers need to be cautious and take the necessary steps to ensure the sustainability of family Takaful in Malaysia.

While the relationship in between the efficiency and competition are discussed comprehensively in the banking industry, there are limited studies on insurance industry. Although several previous studies have investigated the impact of competition on efficiency, their methods are relatively simpler by using the market share as the proxy for competition or market power. Our paper goes beyond the current studies in that it employs a relatively 
complicated Panzar-Rosse method to measure the competition of insurance. This method is more practical to evaluate the competition level as it takes into the account of changes in input prices to reflect the changes in revenues to reveals the firm's capability to pass on increases in input prices to consumers. The paper studies the impact of efficiency to competition which is the reversed direction compared to majority of the studies that examine the consequences of competition on efficiency. Our paper provides novel feature that improves in efficiency will enhance competition in the insurance industry. The findings are valuable for insurance firms and policy makers. The insurance firms should identify the factors that drive their efficiency and make effort to improve the efficiency that enhance the competition in the insurance industry to improve social welfare. The supervision authorities should decide for reforms that promote efficiency that improve the service quality and boost the competition of the industry, as well as to safeguard a balance between competition and prudential regulatory actions.

This study presents opportunities for future study in various directions. One of these opportunities is the impact of the risk-based capital framework on Takaful insurers. Because regulatory development is a global phenomenon, it would be interesting to analyse its impact on the efficiency and competitiveness of Takaful insurers and to determine how the insurers deal with the increasingly complicated business environment. Furthermore, relatively new methods to measure competitiveness, such as the Boone Indicator, could be employed. Another interesting topic worth exploring is the relationship between competitiveness and Takaful soundness (see Cummins et al., 2017).

\section{Acknowledgements}

We thank the editor, Associate Professor Dr Izolda Joksiene, and four anonymous reviewers for their constructive comments which helped us to improve the article.

\section{Author contributions}

Hui Shan LEE was responsible for the write up of the article. Fan Fah CHENG, Annuar Md NASSIR and Nazrul Hisyam Ab RAZAK contributed on the data interpretation.

\section{Funding}

This work was supported by the Malaysian Ministry of Higher Education under Grant [FRGS/1/2017/SS01/UTAR/03/1]; Geran Universiti Putra Malaysia under Grant [GPIPS/2016/9508700]; Universiti Putra Malaysia Journal Publication Fund.

\section{Disclosure statement}

We declare that we have no competing interests. 


\section{References}

Aktan, B., \& Masood, O. (2010). The state of competition of the Turkish banking industry: an application of the Panzar-Rosse model. Journal of Business Economics and Management, 11(1), 131-145. https://doi.org/10.3846/jbem.2010.07

Alhassan, A. L., \& Biekpe, N. (2016). Competition and efficiency in the non-life insurance market in South Africa. Journal of Economic Studies, 43(6), 882-909. https://doi.org/10.1108/JES-07-2015-0128

Alhassan, A. L., \& Biekpe, N. (2017). Liberalization outcomes and competitive behaviour in an emerging insurance market. African Development Review, 29(2), 122-138. https://doi.org/10.1111/1467-8268.12245

Andries, A. M., \& Capraru, B. (2014). The nexus between competition and efficiency: the European banking industries experience. International Business Review, 23(3), 566-579. https://doi.org/10.1016/j.ibusrev.2013.09.004

Apergis, N., \& Polemis, M. L. (2016). Competition and efficiency in the MENA banking region: a nonstructural DEA approach. Applied Economics, 48(54), 5276-5291. https://doi.org/10.1080/00036846.2016.1176112

Asia Insurance Review. (2016). Takaful: Global gross contributions rose by 5\% to US\$23.2 bln in 2015. Retrieved from http://www3.asiainsurancereview.com/News/View-NewsLetterArticle?id=35885\&Type $=$ MiddleEast\#

Banker, R. D., Charnes, A., \& Cooper, W. W. (1984). Some models for estimating technical and scale inefficiencies in data envelopment analysis. Management Science, 30(9), 1078-1092. https://doi.org/10.1287/mnsc.30.9.1078

Biener, C., Eling, M., \& Jia, R. (2017). The structure of the global reinsurance market: an analysis of efficiency, scale, and scope. Journal of Banking \& Finance, 77, 213-229. https://doi.org/10.1016/j.jbankfin.2017.01.017

Biener, C., Eling, M., \& Wirfs, J. H. (2016). The determinants of efficiency and productivity in the Swiss insurance industry. European Journal of Operational Research, 248(2), 703-714. https://doi.org/10.1016/j.ejor.2015.07.055

Bikker, J. A., \& Haaf, K. (2002). Competition, concentration and their relationship: an empirical analysis of the banking industry. Journal of Banking \& Finance, 26(11), 2191-2214. https://doi.org/10.1016/S0378-4266(02)00205-4

Bikker, J. A., \& Leuvensteijn, M. V. (2008). Competition and efficiency in the Dutch life insurance industry. Applied Economics, 40(16), 2063-2084. https://doi.org/10.1080/00036840600949298

Charnes, A., Cooper, W. W., \& Rhodes, E. (1978). Measuring the efficiency of decision making units. European Journal of Operational Research, 2(6), 429-444. https://doi.org/10.1016/0377-2217(78)90138-8

Coccorese, P. (2012). Information sharing, market competition and antitrust intervention: a lesson from the Italian insurance sector. Applied Economics, 44(3), 351-359. https://doi.org/10.1080/00036846.2010.508721

Cummins, J. D., Rubio-Misas, M., \& Vencappa, D. (2017). Competition, efficiency and soundness in European life insurance markets. Journal of Financial Stability, 28, 66-78. https://doi.org/10.1016/j.jfs.2016.11.007

Cummins, J. D., \& Weiss, M. A. (1993). Measuring cost efficiency in the property-liability insurance industry. Journal of Banking and Finance, 17, 463-481. https://doi.org/10.1016/0378-4266(93)90046-G

Cummins, J. D., \& Weiss, M. A. (2013). Analyzing firm performance in the insurance industry using frontier efficiency and productivity methods. In Handbook of insurance (pp. 795-861). New York, NY: Springer. https://doi.org/10.1007/s11123-012-0302-2 
Cummins, J. D., Weiss, M. A., Xie, X., \& Zi, H. (2010). Economies of scope in financial services: A DEA efficiency analysis of the US insurance industry. Journal of Banking and Finance, 34(7), 1525-1539. https://doi.org/10.1016/j.jbankfin.2010.02.025

Cummins, J. D., \& Xie, X. (2013). Efficiency, productivity, and scale economies in the U.S. propertyliability insurance industry. Journal of Productivity Analysis, 39(2), 141-164. https://doi.org/10.1007/s11123-012-0302-2

Eling, M., \& Schaper, P. (2017). Under pressure: how the business environment affects productivity and efficiency of European life insurance companies. European Journal of Operational Research, 258(3), 1082-1094. https://doi.org/10.1016/j.ejor.2016.08.070

Fah, C. F., \& Sin, L. H. (2014). Relationship between earnings response coefficient of insurance firms and exgrowth opportunities, earned premium incomes and commissions in Malaysia. International Business Research, 7(6), 164-173. https://doi.org/10.5539/ibr.v7n6p164

Goud, B. (2016). World Takaful Report 2016. Retrieved from http://www.takafulprimer.com/main/ downloads/ms_5860.pdf

Gujarati, D. N., \& Porter, D. C. (2009). Basic econometrics. Singapore: McGraw-Hill Irwin.

Jeng, V. S. C. (2015). Competition and its variation over time: an empirical analysis of the Chinese insurance industry. The Geneva Papers on Risk and Insurance - Issues and Practice, 40(4), 632-652. https://doi.org/10.1057/gpp.2015.4

Kader, H. A., Adams, M., Hardwick, P., \& Kwon, W. J. (2014). Cost efficiency and board composition under different Takaful insurance business models. International Review of Financial Analysis, 32, 60-70. https://doi.org/10.1016/j.irfa.2013.12.008

Kumar, M., Charles, V., \& Mishra, C. S. (2016). Evaluating the performance of Indian banking sector using DEA during post-reform and global financial crisis. Journal of Business Economics and Management, 17(1), 156-172. https://doi.org/10.3846/16111699.2013.809785

Lee, H. S., Low, K. L. T., Chong, S. C., \& Sia, B. K. (2018). Influence of secondary and tertiary literacy on life insurance consumption: case of selected ASEAN countries. Geneva Papers on Risk and Insurance: Issues and Practice, 43(1), 1-15. https://doi.org/10.1057/s41288-017-0050-7\

Malaysian Takaful Association Annual Report. (2015). Malaysian Takaful Association Annual Report 2015.

Panzar, J. C., \& Rosse, J. N. (1987). Testing for 'monopoly' equilibrium. The Journal of Industrial Economics, 35(4), 443-456. https://doi.org/10.2307/2098582

Spierdijk, L., \& Koning, R. H. (2014). Estimating outstanding claim liabilities: the role of unobserved risk factors. Journal of Risk and Insurance, 81(4), 803-830.

https://doi.org/10.1111/j.1539-6975.2013.01518.x

Sufian, F. (2011). The nexus between financial sector consolidation, competition and efficiency: empirical evidence from the Malaysian banking sector. IMA Journal of Management Mathematics, 22(4), 419-444. https://doi.org/10.1093/imaman/dpr015

The Financial Stability and Payment Systems Report. (2015). The Financial Stability and Payment Systems Report.

Todorov, A. B. (2016). Assessing competition in the Bulgarian insurance industry: a Panzar-Rosse approach. International Journal of Economics and Financial Issues, 6(3), 872-879.

Williams, R. L., Anzsar, J., Bulmer, R., Buntine, J., Byrne, M., Gedalla, B., Goswamy, P., Grant, J., Heah, W., Keshani, S., \& Shah, J. (2016). Application of the solvency II actuarial function to general insurance firms. British Actuarial Journal, 21(3), 476-530. https://doi.org/10.1017/S1357321716000052 